\title{
David B. Audretsch: Clarivate Citation Laureate 2021
}

\author{
Christina Guenther · Erik E. Lehmann
}

Accepted: 8 October 2021 / Published online: 30 October 2021

(C) The Author(s) 2021

Plain English Summary David B. Audretsch was named a 2021 Clarivate Citation Laureate, together with four other colleagues in the field of economics. A Clarivate Citation Laureate is recognized as having a research record and impact commensurate with that deemed to be 'of Nobel class.' This article briefly highlights the life and work of David B. Audretsch, Co-founder and Co-Editor in Chief of Small Business Economics: An Entrepreneurship Journal (SBEJ). Relying on bibliometric work published in the last years, this article briefly highlights the impact and influence of David B. Audretsch in the field of innovation and entrepreneurship.

\section{David B. Audretsch: Clarivate Citation Laureate 2021}

David B. Audretsch was named a 2021 Clarivate Citation Laureate. A Clarivate Citation Laureate is recognized as having a research record and impact commensurate with that deemed to be 'of Nobel class.' A Citation Laureate is named based on the

C. Guenther · E. E. Lehmann $(\bowtie)$

WHU Otto Beisheim School of Management, Faculty of Business and Economics, University of Augsburg, Universitätsstr. 16, 86159 Augsburg, Germany

e-mail: erik.lehmann@wiwi.uni-augsburg.de

C. Guenther

e-mail: christina.guenther@whu.edu citation impact of their published research and they are considered likely to win the Nobel Prize in their respective field. ${ }^{1}$ Clarivate Citation Laureates (formerly Thomson Reuters Citation Laureates) initiated this list in 2002, and the list of awardees is announced annually prior to the Nobel Prize ceremonies of that year.

The award is based on an analysis of Web of Science $^{\mathrm{TM}}$ publication and citation data to identify influential researchers in the topic areas recognized by Nobel Prizes: physiology or medicine, physics, chemistry, and economics. Out of some 52 million articles and proceedings indexed in the Web of Science since 1970 , only 6,500 (or $0.01 \%$ ) have been cited 2,000 or more times. It is from the authors of this group of papers that Citation Laureates are identified and selected. They are individuals whose research publications are highly cited and whose contributions to science have been extremely influential, even transformative. ${ }^{2}$

Clarivate has a notable track record of identifying "Nobel class" research: of the more than 300 who have been named since 2002, 59 Citation Laureates have gone on to receive a Nobel Prize. Audretsch is one of 16 world-class researchers from six countries to receive the honor in 2021. Audretsch is recognized

\footnotetext{
${ }^{1}$ See the list of Clarivate Laureates and the Nobel Price winners respective at https://en.wikipedia.org/wiki/Clarivate_Citat ion_Laureates, accessed 10/02/2021.

${ }^{2}$ https://clarivate.com/citation-laureates/, accessed 02/10/2021.
} 
Table 1 Scientific publications by David Audretsch (citations/year), 2017

Title

Web of Sci-

ence citations

R\&D Spillovers and the Geography of Innovation and Production (1996)

The Knowledge Spillover Theory of Entrepreneurship (2009)

33.5

Innovation in Cities: Science-Based Diversity, Specialization and Localized Competition (1999) 29.2

Innovation in Large and Small Firms: An Empirical Analysis (1988) 22.8

Company-Scientist Locational Links: The Case of Biotechnology (1996) 20.6

Entrepreneurship Capital and Economic Performance (2004) 18.7

Agglomeration and the Location of Innovative Activity (1998) 16.7

New Venture Growth: A Review and Extension (2006) 15.2

Does the Knowledge Spillover Theory of Entrepreneurship Hold for Regions? (2005) 15.1

Does Self-Employment Reduce Unemployment? (2008) 14.1

R\&D Spillovers and Recipient Firm Size (1994) 13.1

New Firm Survival: New Results Using a Hazard Function (1995) 12.7

The Missing Link: Knowledge Diffusion and Entrepreneurship in Endogenous Growth (2010) 12.2

University Spillovers and New Firm Location (2005) 11.6

Growth Regimes over Time and Space (2002) 11.5

The Future of Entrepreneurship Research (2011) 11.4

Innovation, Growth and Survival (1995) 11.1

Innovative Clusters and the Industry Life Cycle (1996) 10.7

The Knowledge Spillover Theory of Entrepreneurship (2013) 10.7

From the Entrepreneurial University to the University in the Entrepreneurial Society (2014) 10.4

The Theory of Knowledge Spillover Entrepreneurship (2007) 10.3

Clusters, Knowledge Spillovers and New Venture Performance (2008) 10.2

Innovation, Market Structure, and Firm Size (1987) 9.9

New-Firm Survival and the Technological Regime (1991) 9.9

Real Effects of Academic Research: Comment (1992) 9.8

Capitalism and Democracy in the 21st Century: From the Managed to the Entrepreneurial Economy (2000) 9.5

Strategic Entrepreneurship: Exploring Different Perspectives of an Emerging Concept (2009) 9.1

Emotions and Opportunities: The Interplay of Opportunity Evaluation, Fear, Joy, and Anger as Antecedent of Entre- 8.9 preneurial Exploitation (2012)

Does Entry Size Matter? The Impact of the Life Cycle and Technology on Survival (2001) 8.4

Entrepreneurship Capital and Economic Growth (2007) 8.4

Gibrat's Law: Are the Services Different? (2004) 7.7

Entrepreneurship Capital and Its Impact on Knowledge Diffusion and Economic Performance (2008) 7.1

Start-Up Size and Industrial Dynamics: Some Evidence from Italian Manufacturing (1999) 7.0

Growth and Entrepreneurship (2012) 7.0

Entrepreneurial Finance and Technology Transfer (2016) 6.7

The Geography of Firm Births in Germany (1994) 6.6

Entrepreneurship and Regional Growth: An Evolutionary Interpretation (2004) 6.4

Knowledge Creation, Entrepreneurship, and Economic Growth: A Historical Review (2009) 6.3

Regional Competitiveness, University Spillovers and Entrepreneurial Activity (2012) 6.3

The Dynamic Role of Small Firms: Evidence from the US (2002) 6.1

Entrepreneurship and Regional Growth: An Evolutionary Interpretation (2004) 6.1

The Emergence of Entrepreneurship Policy (2004) 5.7

Industry Structure, Entrepreneurship, and Culture: An Empirical Analysis Using Historical Coalfields (2016) 5.7

Does Entrepreneurship Capital Matter? (2004) 5.5 
Table 1 (continued)

Title

Web of Sci-

ence citations

Patents as a Measure of Innovative Activity (1989)

Location: A Neglected Determinant of Firm Growth (2007)

Does Firm Size Matter? Evidence on the impact of Liquidity Constraints on Firm Investment Behavior in Germany (2002)

The Role of Small Firms in US Biotechnology Clusters (2003)

Small-Firm Entry in US Manufacturing (1989)

Source: Karlsson and Hammarfelt (2019, p. 174f)

"for pioneering research on entrepreneurship, innovation, and competition" and is one of five scholars named this year in the field of economics, according to Clarivate.

The other scholars recognized as 2021 Citation Laureates are David Teece, University of California at Berkeley, also "for pioneering research on entrepreneurship, innovation, and competition;" Joel Mokyr, Northwestern University, "for studies of the history and culture of technological progress and its economic consequences;" and Carmen M. Reinhart, Harvard University, and Kenneth S. Rogoff, Harvard University, "for contributions to international macroeconomics and insights on global debt and financial crises."

Audretsch is the co-editor of Small Business Economics, which he co-founded with Zoltan J. Acs in 1988. This journal bears his imprint and reflects many years of blood, sweat, and tears invested to create, develop, diffuse, and enhance the field of entrepreneurship and its scholarly community. Audretsch will continue to lead the journal into the future with the incoming co-editor-in-chief, Christina Guenther.

He earned his Ph.D. in economics at the University of Wisconsin in 1980, then accepted an appointment as Assistant Professor at Middlebury College. In 1985, Audretsch joined the Institute of International Management in Berlin, which was later reorganized to its contemporary name, the Wissenschaftszentrum Berlin fuer Sozialforschung (Berlin Center for Social Science Research). It was during his time in Berlin, as Acting Director and Research Professor, that Small Business Economics was founded. In 1997, Audretsch returned to the United States, and eventually settled as the Ameritech Chair of Economic Development and Director of the Institute of Development Strategies at Indiana University, where he was eventually appointed to the rank of Distinguished Professor.

Audretsch was also chosen as the Director of the Max Planck Institute of Economics, where he founded the Research Group on Entrepreneurship, Growth and Public Policy, where he lead until 2010. He also served as the Visiting Research Scholar at the Ewing Marion Kauffman Foundation. He additionally sat on the Scientific Advisory Board of a host of think tanks, research institutes and universities including, the Mannheim Center for European Economic Research (ZEW), Hamburg World Economics Institute (HWWA), German Institute for Economic Research (DIW Berlin), the Basque Institute of Competitiveness, Swedish Foundation for Entrepreneurship, Jackstädt Center for Entrepreneurship and Innovation and the Deutsche Telekom Stiftung. Along the way, he served as Chair of the Entrepreneurship Division of the Academy of Management. He is an Honorary Professor at WHU- Otto Beisheim School of Management, Germany, and has received three Honorary Doctorates, one from the University of Augsburg, Germany, in 2008, one from Jönköping University, Sweden, in 2010, and one from the University of Siegen, Germany, in 2018.

\section{Impact and influence}

Even when quantitative measures, in particular publications included the WoS, are the basis of worldwide rankings of institutions and individuals and accepted as performance measures ( $\mathrm{Li}$ et al., 2019), they are not without criticism. Not only is it questionable 
Fig. 1 The keywords used in David Audretsch's publications (source: Urbano \& Aparicio, 2019, p. 289)

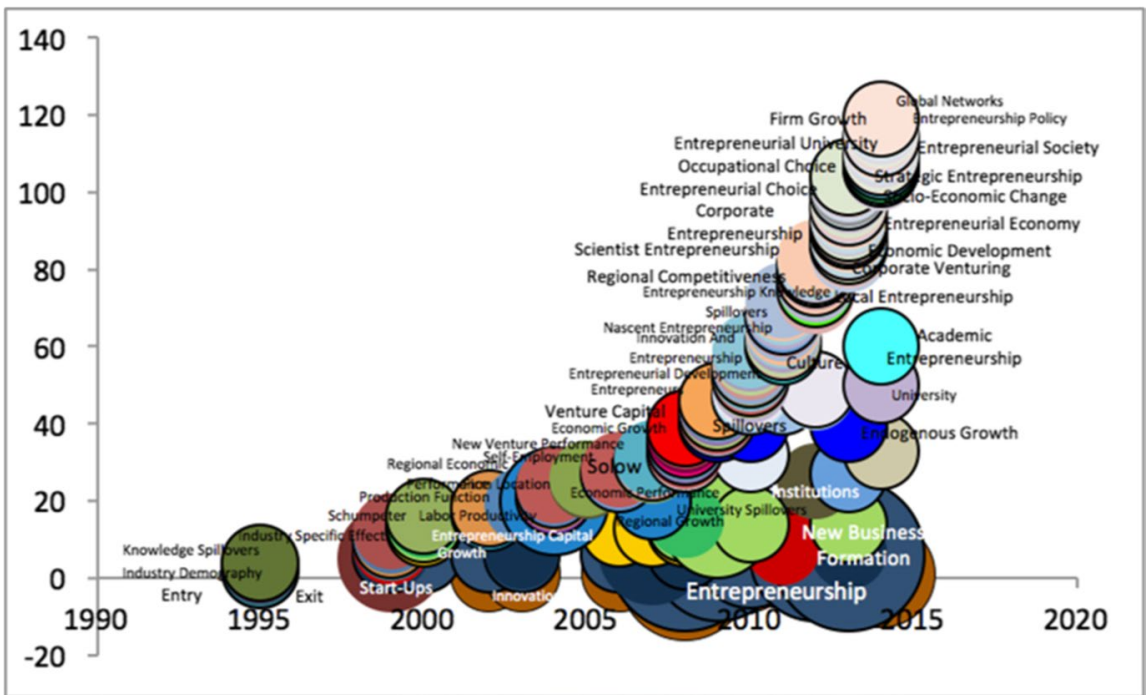

whether scientific quality and influence can be measured at all, but also because of the adverse effects like just 'producing papers' and 'salami slicing,' leading to 'hyperbolic' scientists (Ioannidis et al., 2018). Quantity does not necessarily reflect the influence and impact of these 'hyperbolic' scientists (Bornmann \& Tekles, 2019). One measure to proxy quality and impact is by citations, how often the paper, along with the underlying thoughts, ideas, and results, is used as a worthwhile input for other scientific work, either as supportive or countervailing evidence. An exceptionally high citation record is a mark of a researcher's community-wide influence. It is an acknowledgement of their important foundational work, on which they and others are building further research. This mechanism, as Kuhn (1962) introduced in his book, The Structure of Scientific Revolutions, is the most important and effective one in generating new scientific knowledge, the perception of existing knowledge and also scrutinizing and questioning existing results and evidence. Citations also reflect the shoulders of giants: only those whose thoughts and ideas are worthy of citation generate the scientific foundation for recent and future research and evidence, and thus display the influence of an author's work on others. Therefore, an exceptionally high citation record is a mark of a researcher's influence. The selection of David Audretsch into the group of 'Nobel Class' citation laureates is based on his exceptionally high citation record. A record, that is confirmed by recent bibliometric studies (Urbano
\& Aparicio, 2019; Karlsson \& Hammarfelt, 2019), where Table 1 provides a snapshot of the yearly number of citations until 2018.

Citations may not necessarily measure the whole band width of a scientist's influence and impact. Another measure is interdisciplinarity and the scientific fields in which the scientist contributes, in particular in the social sciences like economics. The career of David B. Audretsch has demonstrated his considerable impact, not only in entrepreneurship and small business research but also in economics as a whole. For instance, Linß (2017) has highlighted Audretsch's academic influence by analyzing the 60 most important economists from Aristotle to Paul Romer and Cancino et al. (2017) and shows that Audretsch is the most influential innovation researcher during the period 1989-2013. In addition, Sanders (2009) has edited a 'farewell' olume dedicated to Audretsch when leaving the Max Planck Institute and in 2019, colleagues, friends, and junior scientists contributed to the extensive "Festschrift," "From Industrial Organization to Entrepreneurship" edited by Lehmann and Keilbach (2019), which details the extensive and broad-reaching impact that Audretsch has had throughout his career.

David B. Audretsch is recognized, "for pioneering research on entrepreneurship, innovation, and competition." This interdisciplinary work is best reflected by the bibliometric study undertaken by Urbano and Aparicio (2019). They show that 


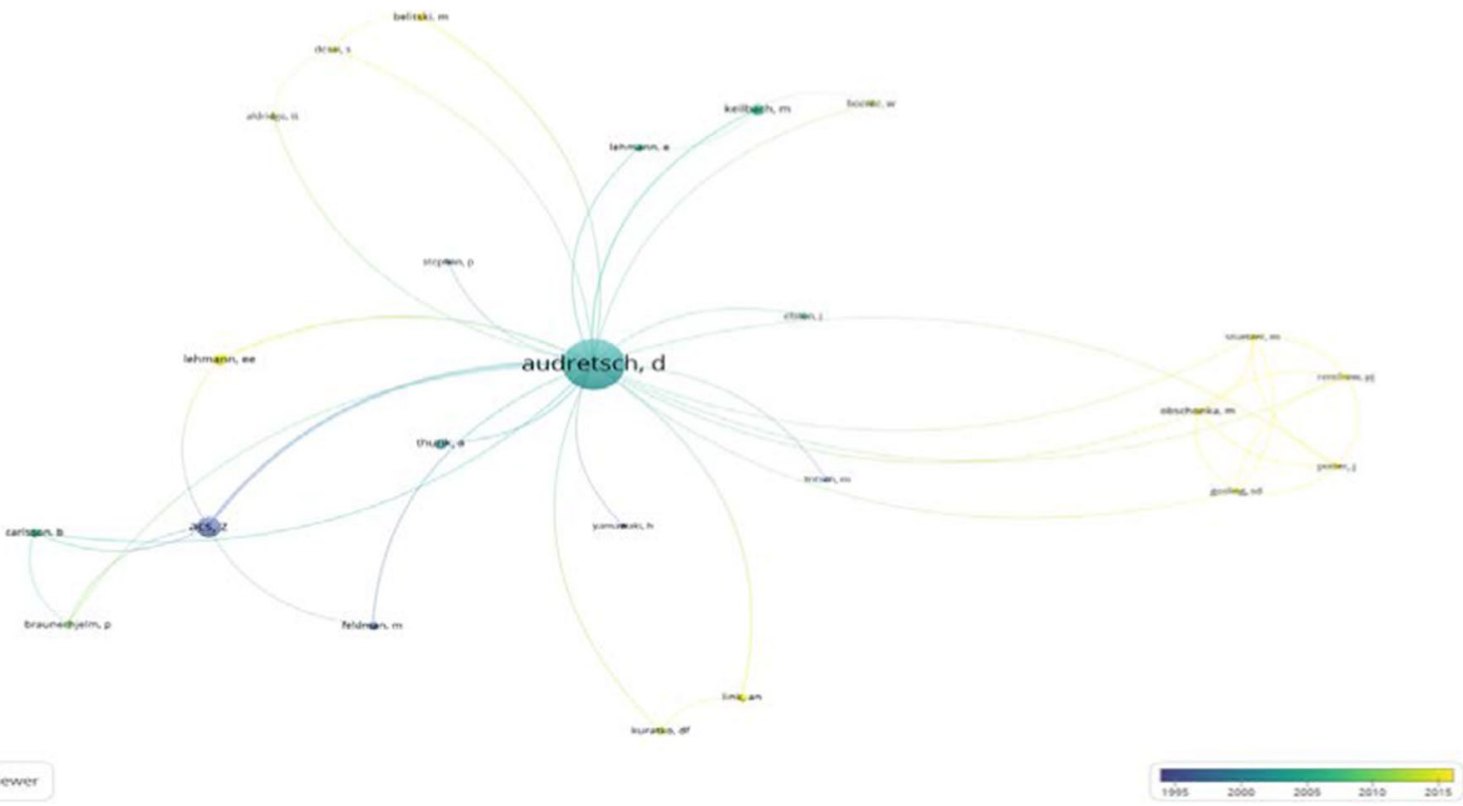

Fig. 2 David Audretsch's co-author network during the period 1983-2018. Source: Karlsson \& Hammarfelt, 2019, p. 186

Audretsch has been a pioneer not only in entrepreneurship but also in related topics such as innovation in large and small companies (innovation), industry development and competitiveness (competition), and more recently, public policy (see Fig. 1).

Another measure of influence and impact is the group of scientists that a researcher works with, their scientific network and community. Karlsson and Hammarfelt (2019) demonstrate the structure and development of David Audretsch's scientific community and collaboration network mirrored by his network of co-authors. Starting with Zoltan Acs, co-founder of Small Business Economics in the 1980s, the network has developed over time
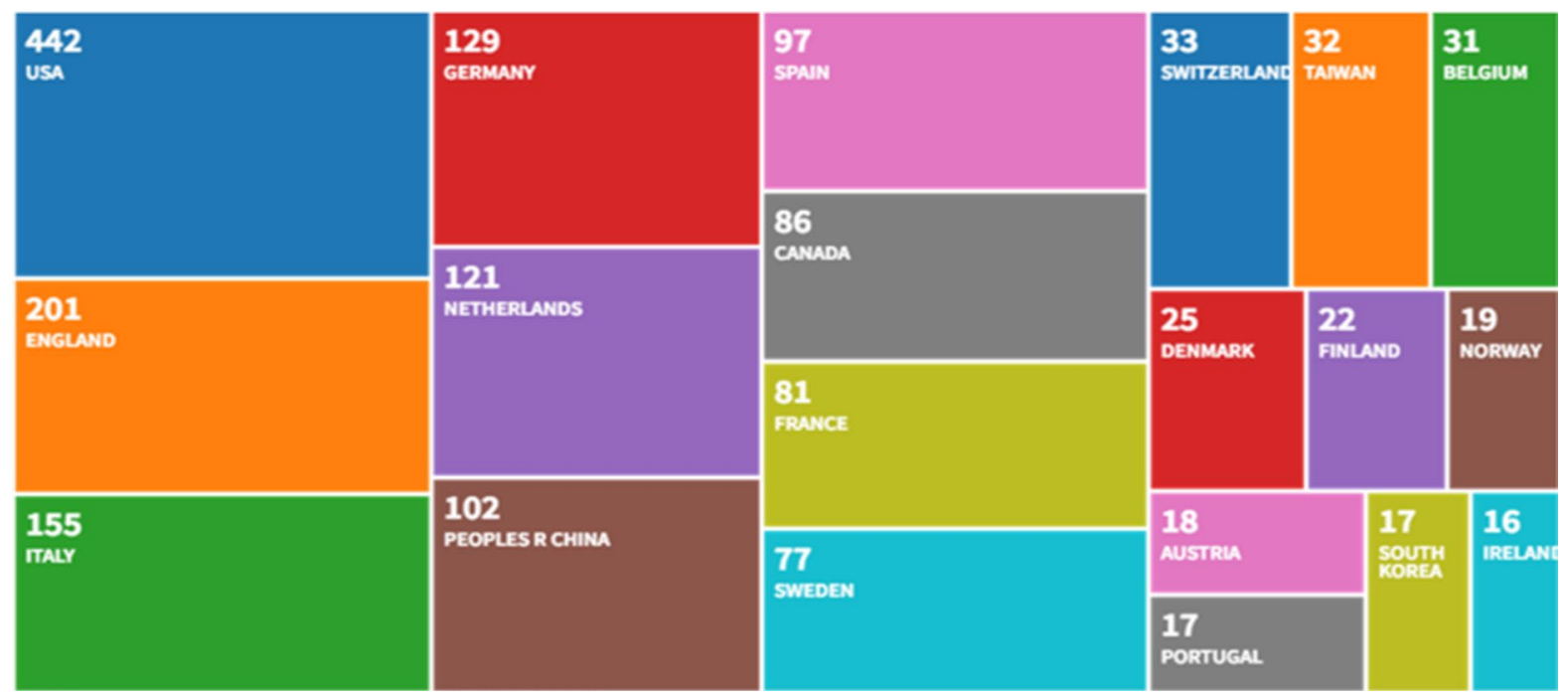

Fig. 3 The geographical distribution of David Audretsch's citations. (source: Karlsson \& Hammarfelt, 2019, p. 188) 
(see Fig. 2). However, as Karlsson and Hammarfelt conclude (p. 182f.): "What is noticeable here is that even if the number of co-authors has grown rapidly over time, David Audretsch continues to publish together with his since long-established co-authors. The result is nothing less than a very impressive and productive scientific co-operation network."

Finally, in a globalized world, influence and impact of a scientist should also be reflected by a global recognition of their work. Figure 3 depicts the distribution of citations worldwide, focusing on 2018 (Karlsson \& Hammarfelt, 2019, p. 188). In particular, three geographical clusters could be identified, namely, North America (USA and Canada), Europe, and Asia (China, South Korea).

\section{Roots and wings}

This recognition, as impressive as it is, does not do justice to the impact that Audretsch has had on Small Business Economics and the entire field of entrepreneurship. In The Makers of Modern of Entrepreneurship, he emphasizes the importance of roots and wings (Audretsch, 2017). The classic greater thinkers, such as Joseph A Schumpeter, gave this field the roots. Everyone who had the chance to work with or meet Audretsch knows that his impact on the field goes way beyond his groundbreaking and inspirational papers that have been cited so extensively. His passion to build and grow a community and to provide the next generation of researchers with roots and wings is omnipresent and rousing. Opening doors, especially for young and talented scholars, connecting people and providing feedback to advance our understanding of entrepreneurship have always been at the core of his activities. With this spirit and mission to provide a scientific home for the community, it is David Audretsch who has graced us with the wings to move beyond those roots.

Funding Open Access funding enabled and organized by Projekt DEAL.
Open Access This article is licensed under a Creative Commons Attribution 4.0 International License, which permits use, sharing, adaptation, distribution and reproduction in any medium or format, as long as you give appropriate credit to the original author(s) and the source, provide a link to the Creative Commons licence, and indicate if changes were made. The images or other third party material in this article are included in the article's Creative Commons licence, unless indicated otherwise in a credit line to the material. If material is not included in the article's Creative Commons licence and your intended use is not permitted by statutory regulation or exceeds the permitted use, you will need to obtain permission directly from the copyright holder. To view a copy of this licence, visit http://creativecommons.org/licenses/by/4.0/.

\section{References}

Audretsch, D. B. (2017). Roots and Wings. In D. B. Audretsch \& E. E. Lehmann (Eds.), The Routledge Companion to the Makers of Modern Entrepreneurship (pp. 32-41). Routledge.

Bornmann, L., \& Tekles, A. (2019). Productivity does not equal usefulness. Scientometrics, 118, 705-707. https:// doi.org/10.1007/s11192-018-2982-5

Cancino, C. A., Merigó, J. M., \& Coronado, F. C. (2017). Big Names in Innovation Research: A Bibliometric Overview. Current Science, 113, 1507-1518.

Ioannidis, J. P. A., Klavans, R., \& Boyack, K. W. (2018). Thousands of scientists publish a paper every 5 days. Nature, 561(7722), 167-169.

Karlsson, Ch. ., \& Hammarfelt, B. (2019). David Audretsch A Bibliometric Portrait of a Distinguished Entrepreneurship Scholar. In E. E. Lehmann \& M. Keilbach (Eds.), From Industrial Organization to Entrepreneurship. A Tribute to David Audretsch (pp. 169-192). Springer.

Kuhn, T. S. (1962). The Structure of Scientific Revolutions. University of Chicago Press.

Lehmann, E. E., \& Keilbach, M. (Eds.). (2019). From Industrial Organization to Entrepreneurship. A Tribute to David. Heidelberg/New York.

Li, J., Yin, Y., Fortunato, S. \& Wang, D. (2019) A dataset of publication records for Nobel laureates. Scientific Data 6(33). https://doi.org/10.1038/s41597-019-0033-6

Linß, V. (2017). Die wichtigsten Wirtschaftsdenker. Marix Verlag. Sanders, M. (2009). Reflections: A farewell to David. Now Publisher.

Urbano, D., \& Aparicio, S. (2019). An Overview of the Economics of Entrepreneurship and Small Business: The Legacy of David Audretsch. In E. E. Lehmann \& M. Keilbach (Eds.), From Industrial Organization to Entrepreneurship. A Tribute to David Audretsch (pp. 279-306). Springer.

Publisher's note Springer Nature remains neutral with regard to jurisdictional claims in published maps and institutional affiliations. 